\title{
The Significance of Domestic Financing for Economic Growth in the South East European Countries ${ }^{4}$
}

Article history:

Received: 29. November 2015

Sent for revision: 12 December 2015

Received in revised form: 21 January 2016

Accepted: 28 January 2016

Available online: 1 April 2016

Abstract: In the South East Europe countries, bank loans are common and the most important form of financing, due to still underdeveloped financial market. The banks in these countries gained a considerable amount of foreign funds and play a prominent role in the growth of local economy. Given that banks grant loans based on investments of foreign capital and domestic deposits, the aim of this paper is to determine the importance of domestic sources of financing for the economic growth in the period after the reduction of foreign investments. The survey was conducted on a sample of eight selected countries of South East Europe (Western Balkans along with three countries that became members of the European Union during 20072012 - Bulgaria, Croatia and Romania - SEE-8). The panel data model was applied, where the GDP growth rate was taken as the dependent variable, while the analyzed independent variables were growth rates of the following parameters: assets, loan capacity, the participation of loans in GDP, loan capacity of the population, deposit capacity, deposit of the population, participation of household deposits in total deposit liabilities. The research results indicate that the growth rate of assets, the growth rate of household deposits and the growth rate of retail deposits have a positive impact on economic growth, while the share of loans in GDP, the growth rate of loans

\footnotetext{
${ }^{1}$ Economics Institute, Belgrade,Serbia, sanja.filipovic@ecinst.org.rs

2 University Singidunum, Faculty of Business in Belgrade, Serbia

3 University Singidunum, Faculty of Economics, finance and administration, Belgrade

${ }^{4}$ This paper is a part of research projects No. 179011 and No. 47009 financed by the Ministry of Education, Science and Technological Development of the Republic of Serbia.
} 
Filipović S. et al.: The Significance of Domestic Financing for Economic Growth in the..

to households and the growth rate of deposit capacity have a negative impact on economic growth in SEE-8.

Key words: economic growth, South Eastern Europe, panel data.

\section{Značaj domaćih izvora finansiranja za ekonomski rast u zemljama Jugoistočne Evrope}

Apstrakt: U zemljama Jugoistočne Evrope bankarski krediti predstavljaju najznačajniji vid finansiranja s obzirom da je finansijsko tržište nedovoljno razvijeno. Banke u ovim zemljama su privukle značajan iznos inostranih sredstava i imaju značajnu ulogu u kreiranju ekonomskog rasta. Kako banke odobravaju kredite na bazi plasmana inostranog kapitala i domaćih depozita, cilj rada je da utvrdi značaj domaćih izvora finansiranja na ekonomski rast $u$ periodu nakon redukovanja plasmana iz inostranstva. Istraživanje je sprovedeno na uzorku od osam izabranih zemalja Jugoistočne Evrope (zemlje Zapadnog Balkana i tri zemlje koje su u međuvremenu postale članice Evropske unije - Bugarska, Hrvatska i Rumunija - SEE-8) u vremenskom periodu 2007-2012. godine. Primenjen je panel data model gde je kao zavisna promenljiva uzeta stopa rasta BDP-a, a kao nezavisne promenljive analizirane su stope rasta sledećih parametara: aktiva, kreditni potencijal, učešće zajmova u BDP-a, kreditni potencijal stanovništva, depozitni potencijal, depozit stanovništva, učešće depozita stanovništva u ukupnim depozitima pasive. Rezultati istraživanja ukazuju da stopa rasta aktive, stopa rasta depozita stanovništva i stopa rasta učešća depozita stanovništva imaju pozitivan uticaj na ekonomski rast, dok učešće zajmova u BDP-u, stopa rasta kredita stanovništvu i stopa rasta depozitnog potencijala imaju negativan uticaj na ekonomski rast u SEE-8.

Ključne reči: ekonomski rast, Jugoistočna Evropa, panel data.

\section{Introduction}

The South East European region (SEE) including five Western Balkan countries (Albania, Bosnia and Herzegovina, FYR Macedonia, Montenegro, Serbia) and three new European Union (EU) member states (Bulgaria, Romania and Croatia) were good examples of emerging market economies which attracted a huge amount of foreign capital inflow, which accelerated their economic growth during 2000 until escalation of global economic crisis. The inflow of foreign capital was highly supported by positive expectations regarding EU integration process in these countries (Filipovic, 2012) as well as liberalization of their financial markets. The inflow of foreign investment capital was in form of foreign direct investments (FDI), cross-border credits 
Filipović S. et al.: The Significance of Domestic Financing for Economic Growth in the..

(CBC) or parent bank financing in foreign currency $(\mathrm{FX})$, portfolio investments (PI) and remittances (REM).

Banking sector of SEE-8 countries attracted a huge share of foreign investment capital as a result of privatization process and liberalization of financial market. However, SEE-8 banking sector is highly concentrated (Barjaktarovic et. al; 2013). Top five foreign banks hold the majority of collected deposits and approved loans (the values of concentration index CR5 are in the range from $46 \%$ to $85 \%$ ). The majority of local banks in SEE-8 are foreign (RZB, 2012) and key regional players are banks headquartered in Austria, Greece and France. By the end of 2012, the aggregated SEE exposure of the three most important banking sectors for the region were: Austria, Italy and France, which represent about $50 \%$ of the total regional exposure of European banks, or $45 \%$ of global cross border SEE exposure, which reached more or less the maximal level in 2009 (Popovici, 2012).

Banking sector has the important role for SEE-8 economies and have direct impact on development of gross domestic product (GDP). The huge inflow of capital increased domestic demand in SEE countries and resulted in spreading business and supporting customer's needs cross-border, especially by establishing subsidiary (daughter banks). Furthermore, many internationally active banks had granted long-term loans in the host SEE countries, through their local subsidiaries or directly on the basis of guarantee issued by local subsidiary. Therefore banks in the SEE countries didn't feel the impact of world's economic crisis before the end of 2008 (Marinković and Malović, 2015), which was the case with majority of Central Eastern European countries (CEE). It was the result of implemented risk management processes within the banks, where primary source of repayment of the loan i.e. income (salary) was the basis for granting the loans. Banks weren't highly exposed to risky collaterals, as secondary source of repayment of the loan. However, drop of foreign capital (as CBC or equity decrease) was evident, which had impact on economic growth.

The research done by Chowdhury and Keller (2012) showed that many emerging market economies experienced a surge in capital inflows in the wake of the global financial crisis, which pose a threat to their economic and financial stability. Furthermore, Hermann and Mihaljek (2010) stressed that during this crisis it turned out that $\mathrm{CBC}$ represented the main mechanism for transmission of the crisis. The assets of West European banks in CEE accounted for $10 \%$ of GDP in developed countries (this indicator was about $2.5 \%$ of GDP for American, Canadian and Japanese banks) at the end of 2007. This confirms that CEE recorded the relatively highest CBC inflows.

Chang (2011) confirmed that GDP per capita (GDP pc) for nine EasternEuropean countries during the period 1969-2009 recorded a steady rate of growth thanks to heavy dependence on global markets and capital flows. 
Filipović S. et al.: The Significance of Domestic Financing for Economic Growth in the..

Using panel data model for 20 transition economies in period 2004-2010, Vujovic et al. (2011) tested the impact of fiscal deficit, external debt, inflation and guarantee balance account on GDP. The results showed that export orientation, adequate speed and quality of reforms and key policies had effect on GDP growth and competitiveness. Filipovic and Miljkovic (2014) analysed the impact of global economic crisis on 29 transition economies. Using difference in differences (DinD) methodology they tested the strength of relation between progress in transition reform and GDP rate. The results of research showed that countries with slower progress of reforms felt less negative effects of the crisis with regard to GDP growth rate.

Analysing the influence of various foreign sources of financing (CBC, FDI, PI and REM) on citizens' wealth (expressed as GDP pc) in 15 CEE countries in the period 2005-2010, Savic et. al (2014) confirmed that CBC had the biggest impact on citizen's wealth and those group of countries. Pitic et al. (2014) included same foreign source of financing on the citizens' wealth (GDP pc), on the basis of (shorter) sample on nine CEE countries in the (longer) period from 2005 to 2012. Panel regression confirmed that CBC (as the most expensive source of financing) had the greatest impact on GDP pc as CBCs, during the crisis.

Having in mind that all previous research covered the quality of macroeconomic fundamentals (monetary and fiscal side), progress and quality of institutional reforms, dependence on foreign trade and source of financing and social commitments, in this paper the authors decided to focus on local source of financing. Having in mind that credit approved by local bank is the basic way of financing company's or individual needs in SEE-8 countries (due to low level of development of the financial market), deposits (savings) are the basic source of granting the loan to the customer in those countries. Furthermore, it is confirmed by Vienna's initiative regarding the minimum level of loan to deposit ratio in daily business of regionally active banks in SEE-8 countries. Finally, all of those indicators can be quantified and expressed on the same way (unit).

The aim of this paper is to determine the impact of domestic sources of financing on economic growth in eight SEE countries (SEE-8). The following indicators are analysed as domestic sources of financing: banks' deposit capacity with special focus on retail deposits and its participation in total deposits within banks' liabilities, banks' loan capacity as part of assets and including indicator loans comparing to GDP emphasizing importance of retail loan capacity .

The results of research are analysed between five WB countries (Albania, Bosnia and Herzegovina, FYR Macedonia, Montenegro and Serbia) and 3 EU countries (Bulgaria, Croatia and Romania). A criterion which was applied on chosen country sample is their geographical and political connection, 
Filipović S. et al.: The Significance of Domestic Financing for Economic Growth in the..

macroeconomic profile as well as national consensus on EU integration three countries are already in EU, and five countries are in the process of accession (as Western Balkan region). The research covers the period from 2007 to 2012, since 2007 is the year before escalation of global economic, while 2012 is the last year with data available for all analysed countries. It is evident that all SEE-8 countries felt the first wave of crisis at the end of 2008 , and they had improvements in GDP in the first half of 2011. There were no important movements for analysis in 2012.

The paper is organized as follows. Section 2 gives overview of methodology of the research including brief description of the used model as well as all variables used in the analysis. The section 3 is focused on empirical analysis where results of research were analysed and discussion is developed. Finally, in section 4 are defined the main conclusions and policy recommendations.

\section{Methodology of research}

\subsection{Panel data model}

The aim of this paper is to define the relation between GDP growth and the corresponding banking indicators. In the analysis, the panel data is used for eight countries (Albania, Bosnia and Herzegovina, Bulgaria, Croatia, FYR Macedonia, Montenegro, Romania and Serbia) over the six years' period (from 2007 to 2012).

The dependent variable of this model is the growth rate of GDP. Independent variables, which affect the dependent variable are: (1) growth rate of assets, (2) rate of loan capacity, (3) participation of loans in GDP, (4) rate of retail loan capacity, (5) rate of deposit potential, (6) rate of retail deposits and (7) participation of retail deposits in total deposits. All indicators are expressed in percentage (\%), i.e. as ratio numbers (as same measure units) in order to provide model which will have significant importance.

Data is provided on sites of central banks subject of analysis, International Monetary Fund and RZB Research. The observed data were of longitudinal type, also called cross-sectional, given as concurrent time series data for the group of countries (entities). Organized this way, often referred to as the panel data, they are suitable for hierarchical modelling. In the panel data certain regularity may be observed and effects between entities i.e. between some countries, or within a certain period of time, or finally between the countries and time. The main problem of coping with it are incomplete panel data, their lack or inaccessibility at certain time periods. Considering the nature of data, usage of panel regression is an obvious choice. Preliminary analysis 
Filipović S. et al.: The Significance of Domestic Financing for Economic Growth in the..

examines panel data, analyzing the dependent variable both by country, and by year.

There are two most commonly used models in the analysis of panel data, using the panel regression - the fixed-effects and the random effects model. The fixed effects model deals with changes within the entity, i.e. this model explores the relationship between the dependent variable and independent variables within the entity. It is recommended to use the FE model whenever the variability within a certain entity in analyzed over a period of time. Each entity has its own individual characteristics that affect or not affect the variables. The equation for the fixed effects model becomes:

Yit $=\beta$ Xit $+\alpha i+$ uit, where

Yit is the dependent variable, $\beta$ is the coefficient for that, ai is the unknown intercept for each entity ( $n$ entity-specific intercepts), where $i=$ entity and $t=$ time, Xit represents one independent variable, uit is the error term.

The error term in the previous equation provides that any value within the entity do not lead to biased results of the dependent variable. For this reason, there is a correlation between entity's error term and predictor variables. Model FE ignores temporal influence of independent variables on the dependent variable. Another important premise of the FE model is that the time-invariant characteristics of one entity are not correlated with any other of its individual characteristics. Each entity in the model is different and therefore error and regression coefficient of one entity should not be correlated with the others.

"The fixed-effects model controls for all time-invariant differences between the individuals, so the estimated coefficients of the fixed-effects models cannot be biased because of omitted time-invariant characteristics. One side effect of the features of fixed-effects models is that they cannot be used to investigate time-invariant causes of the dependent variables. Technically, time-invariant characteristics of the individuals are perfectly collinear with the person [or entity] dummies. Substantively, fixed effects models are designed to study the cases of changes within a person. A time-invariant characteristic cannot cause such a change, because it is constant for each person." Kohler Ulrich et al (2009), Data Analysis Using Stata, 2nd ed., p.245

In order to discern specific effects of each analyzed country and year in the model, the fixed-effects method with dummy variables is used, based on the least squares method. Introduction of dummy variables provides some cutouts for each country and each year (entities), while the coefficients that represent gradients in the model are constants. 
Filipović S. et al.: The Significance of Domestic Financing for Economic Growth in the..

\subsection{Analysis of key variables used in the model}

All SEE-8 felt the first wave of economic crisis in 2009 and the rate of GDP growth (\%) in all countries had the same trend of fluctuations during the 20072012 period. The highest level of achieved rate of GDP growth was in 2008, while the lowest level was in 2009 (Figure 1). WB countries had better adoption to world economic crisis and achieved higher rates of GDP growth in comparison with three EU countries.

Figure 1. Rate of GDP growth in SEE-8 for the period 2008-2012

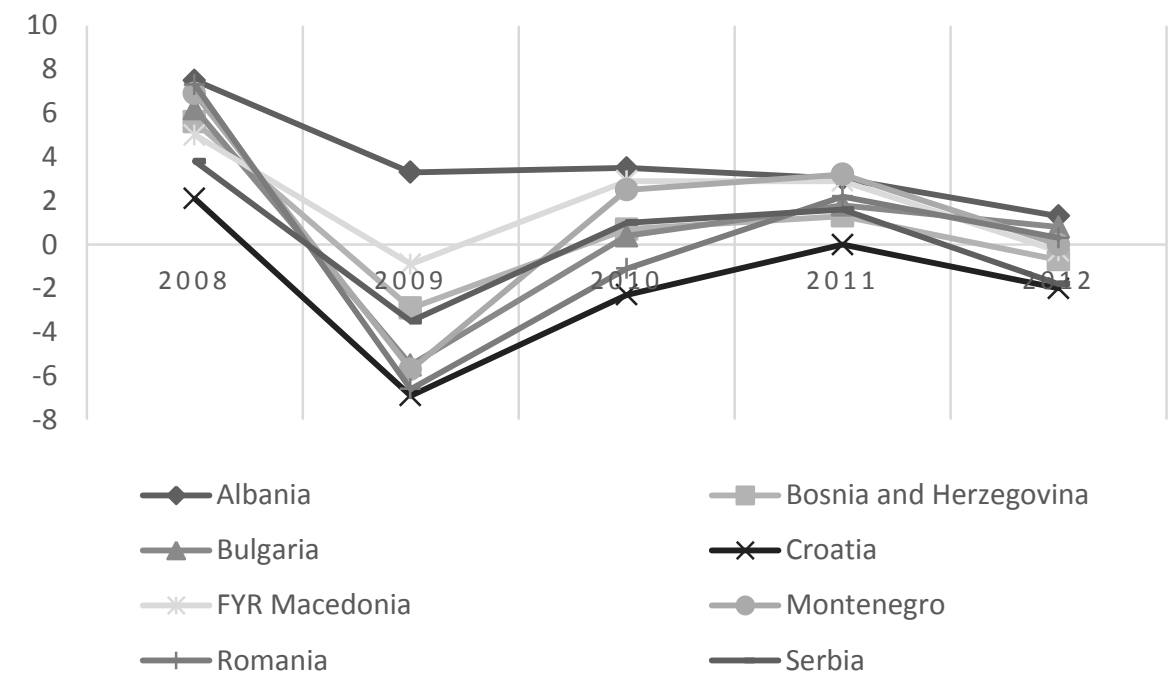

Source: IMF (2013) Regional Economic Issues Central, Eastern and South-Eastern Europe, April 2013, p. 16.

On the basis of analysed trends of assets' indicators in SEE-8 countries (assets in absolute amount, assets/GDP and growth rate of assets), authors concluded that the growth rate of assets is the most relevant indicator for further analysis. Moreover, growth of assets should result from increased credit activity in the function of improving industry i.e. economic growth. Growth rate of assets represents objective movements of banks' operation in SEE-8 region, as a result of banks' actions headquartered abroad to remove equity abroad and central banks' measures how to provide stability of financial market and keep satisfied level of investment activities of banks. Furthermore, assets and assets/GDP are denominated in EUR, which have limitations in the analysis - authors applied middle rate on figures on the last day of the 
Filipović S. et al.: The Significance of Domestic Financing for Economic Growth in the..

year, but the rate fluctuated during the year. Finally, GDP had fluctuation during the crisis and in general decreasing trend during the analysed period, so the achieved values of assets/GDP are not in accordance with movements of GDP.

Growth rate of assets in SEE-8 countries was the highest in 2007, while the lowest was in 2012 (Figure 2). It is in accordance with trends on Emerging markets (Mihaljek, 2011). WB countries achieved higher values of indicator comparing to three EU countries. Montenegro had dramatically different values of indicator comparing to all SEE-8 due to the measures of the Central Bank of Montenegro: 1) Approved acquisitions of local banks and new foreign banks had expansion in 2007, 2) Implemented measures connected to Vienna's initiative and local measures in order to provide stability of financial market from 2009.

Figure 2. Growth rate of assets in SEE-8 in 2007-2012

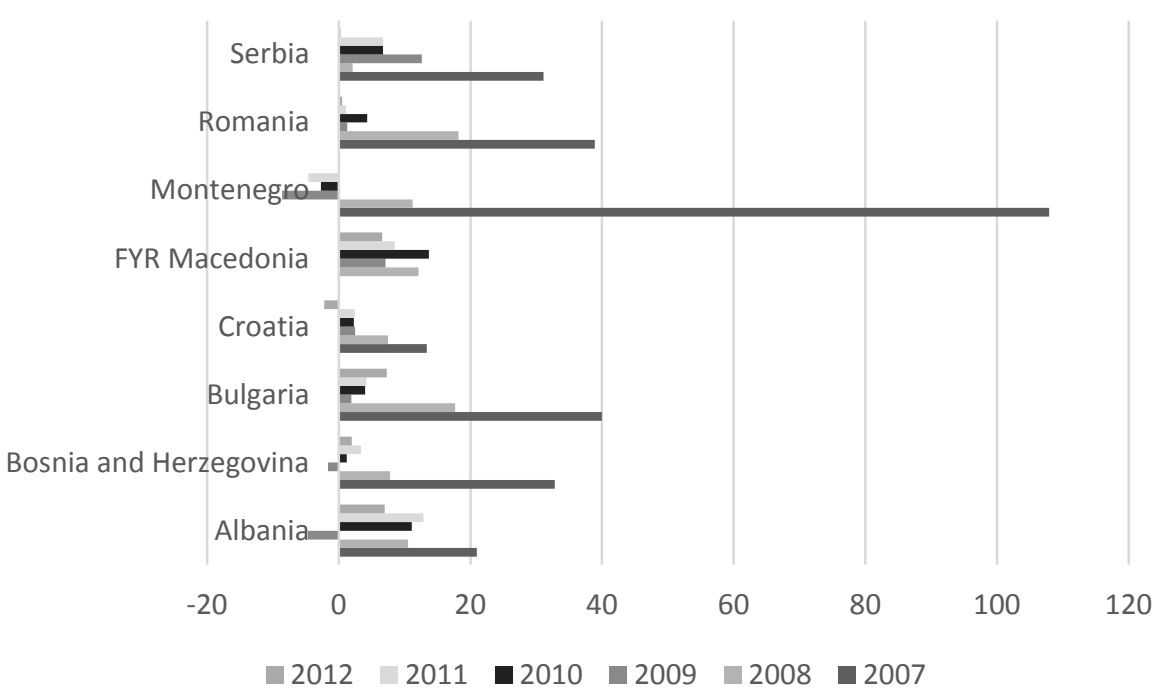

Source: RZB (2010, 2013) Raiffeisen Research, CEE banking sector report 2010, and 2013.

SEE-8 countries kept stable participation of loans in GDP despite negative effects of economic crisis (RZB, 2012), due to taken measures by the central banks (as a result of Vienna's initiative). It confirms that banks' loans are important way of financing SEE-8 economy growth (Figure 3) i.e. it is in accordance with movements in OECD countries where credits affect GDP development (Cecchetti et. al, 2011). Furthermore, loans have bigger impact 
Filipović S. et al.: The Significance of Domestic Financing for Economic Growth in the..

on development of GDP in 2 (out of 3 ) EU countries compared to WB countries. Romania was discovered later by foreign investors, and has relatively low openness comparing to all EU countries. In 2008 there were cyclical fiscal fluctuations with higher inflation and public deficit than it was expected, as well as new political elections which had impact on drop of banks' credit activity. Moreover, there was out-flow of foreign equity $(94.8 \%$ foreign banks in terms of equity in 2008). So, those factors had effect on movements of this indicator in the analysed period. Finally, it can be concluded that WB countries use other sources of financing to stimulate industry activity.

Figure 3. Participation of loans in GDP (\%)

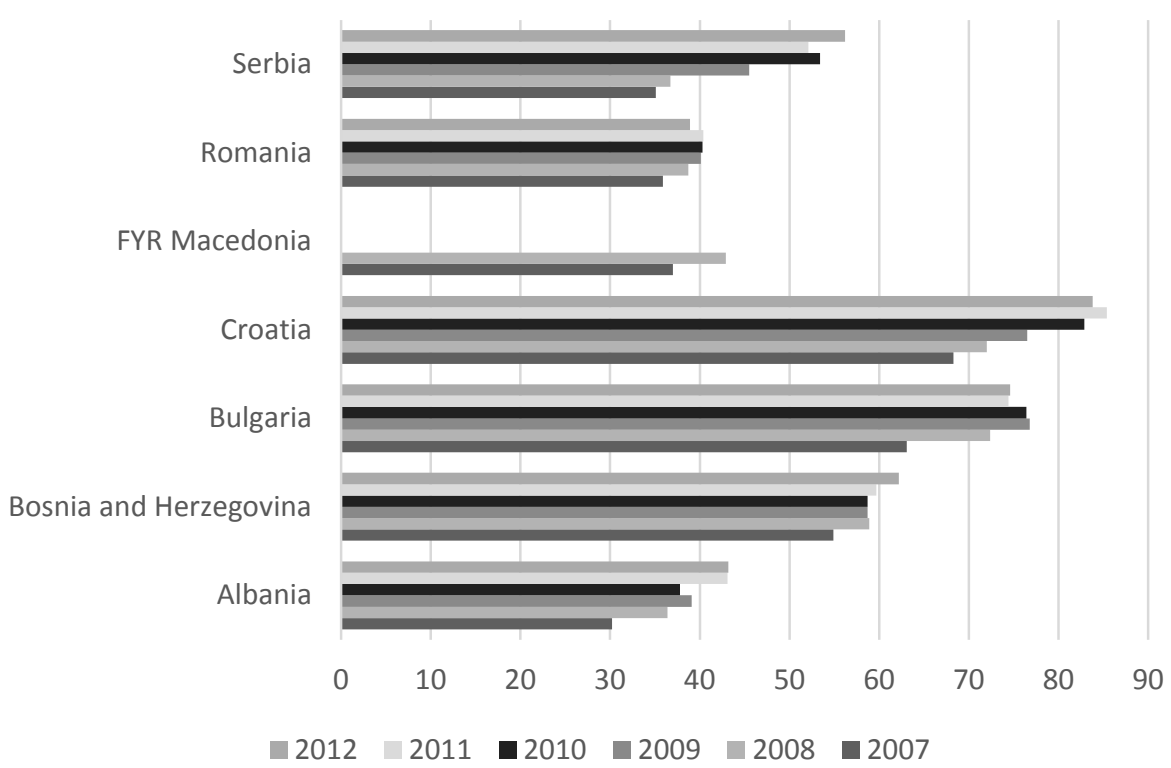

Source: RZB (2007-2012) RZB Research, CEE Reports; Data for FYR Macedonia were available only for 2007 and 2008 (National bank of Macedonia, Report on Banking System of the Republic of Macedonia in 2012) while for Montenegro data were not available.

Rate of loan capacity and rate of retail loan capacity have the same trend as the growth rate of assets in the analysed period. It is in accordance with trends on Emerging markets (Mihaljek, 2011). In addition, it is interesting to notice that WB countries generally achieved higher values of this indicators comparing to three EU countries (Figure 4). Bulgaria has different values of indicator comparing to other EU countries. The reasons were the implemented measures of the Central Bank of Bulgaria, such as: 1) adopted 
Filipović S. et al.: The Significance of Domestic Financing for Economic Growth in the..

and implemented Recovery Plan in the function of stability of banking sector, 2) adopted minimum deposit guarantees by amending the Bank Deposit Guarantee Law. The government adopted three packages of measures for counteracting the crisis, with relevant finance included in the 2009 State Budget Law (such as Minimum Required Reserves and other reserves maintained /including possibility of access/ by Bulgarian National Bank) in order to provide liquidity. 3) Fixed rate of EUR and BGN. It resulted in increased household consumption as a result of growing wages and favorable credit conditions. However, capital out-flow occurred in 2008 (79\% of banks are in foreign ownership in 2008). Furthermore, the elections in 2008 had impact on fiscal cyclical movements and banking sector activity. Described trends in banking sector continued during the analyzed period.

Figure 4. Growth rate of loan capacity in SEE-8

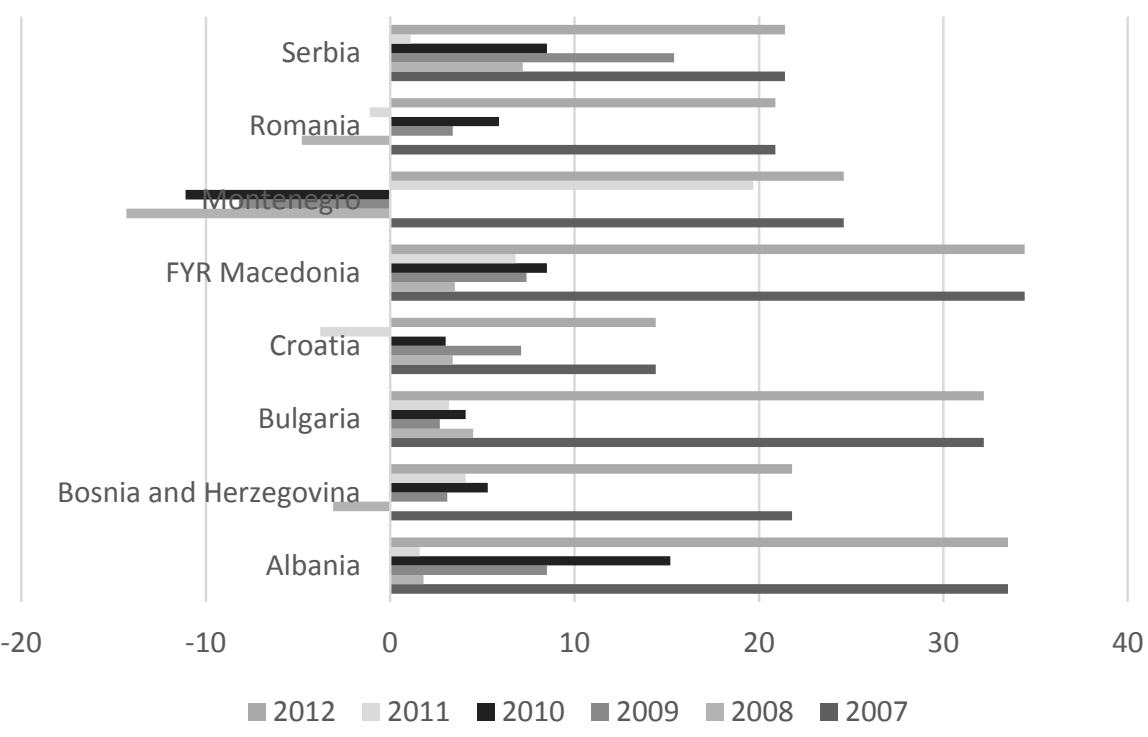

Source: RZB (2010) Raiffeisen Research, CEE banking sector report, September 2010; Central bank of Montenegro (2011) Statistical Bulletin, Central Bank of Macedonia (2012) Report on Banking System of the Republic of Macedonia in 2012.

The structure of banking sector liabilities did not change in SEE-8 in the analysed period. According to Table 1 equity in SEE-8 countries is on a lower level compared (on the average below 20\%) to the level of borrowed funds (on the average above $80 \%$ ). 
Filipović S. et al.: The Significance of Domestic Financing for Economic Growth in the..

Table 1. Structure of banking liabilities in SEE countries (in \%)

\begin{tabular}{|c|c|c|c|c|c|c|c|}
\hline & $\begin{array}{c}\text { Source of } \\
\text { Financing/ } \\
\text { Year }\end{array}$ & 2007 & 2008 & 2009 & 2010 & 2011 & 2012 \\
\hline \multirow{2}{*}{ Serbia } & Liabilities & 79 & 76.4 & 79.3 & 80.3 & 79.4 & 79.5 \\
\hline & Capital & 21 & 23.6 & 20.7 & 19.7 & 20.6 & 20.5 \\
\hline \multirow{2}{*}{ Croatia } & Liabilities & 87.5 & 86.5 & 86.1 & 86.1 & 86.3 & 85.7 \\
\hline & Capital & 12.5 & 13.5 & 13.9 & 13.9 & 13.7 & 14.3 \\
\hline \multirow{2}{*}{ Bosnia and Herzegovina } & Liabilities & 91.5 & 89.9 & 89.8 & 89.1 & 87.4 & 87.3 \\
\hline & Capital & 9.5 & 10.1 & 10.2 & 10.9 & 12.6 & 12.7 \\
\hline \multirow{2}{*}{ Montenegro } & Liabilities & 92 & 91.6 & 89 & 89.4 & 89.2 & 89.7 \\
\hline & Capital & 8 & 8.4 & 11 & 10.6 & 10.8 & 10.3 \\
\hline \multirow{2}{*}{ Macedonia } & Liabilities & 88.5 & 88.6 & 88.6 & 89.4 & 89 & 88.8 \\
\hline & Capital & 11.5 & 11.4 & 11.4 & 10.6 & 11 & 11.2 \\
\hline \multirow{2}{*}{ Romania } & Liabilities & 90.1 & 89.3 & 87.9 & 86.3 & n.a & n.a \\
\hline & Capital & 9.9 & 10.7 & 12.1 & 13.7 & n.a & n.a \\
\hline \multirow{2}{*}{ Bulgaria } & Liabilities & 89.5 & 88.6 & 86.7 & 86.4 & 86 & 86.8 \\
\hline & Capital & 10.5 & 11.4 & 13.3 & 13.6 & 14 & 13.2 \\
\hline \multirow{2}{*}{ Albania } & Liabilities & 92.4 & 91.4 & 90.4 & 90.4 & 91.3 & 91.4 \\
\hline & Capital & 7.6 & 8.6 & 9.6 & 9.4 & 8.7 & 8.6 \\
\hline
\end{tabular}

Source: Sites of central banks of SEE-8.

Commercial banks are creating their own financial potential on the basis of collecting available funds (deposits) from retail and corporate customers (Malović and Paunović, 2012). Furthermore, basic aim of credit institutions is permanent growth of deposit potential. It is the most important source of banks' financing (Barjaktarovic and Dimic, 2014).

Authors find out that participation of banks' deposits in GDP is not relevant for further analysis, because of an evident relation between deposit growth and GDP growth. It is in accordance with the research done by Jurman (2008). Rate of deposit potential and rate of retail deposit potential have the same trend - the values were the highest in 2007 and the lowest in 2012. Generally speaking, the values of these indicators were higher in WB than in three EU countries. 
Filipović S. et al.: The Significance of Domestic Financing for Economic Growth in the..

Rate of deposit potential (Figure 5) implies that three EU countries respect more the fulfilment of loan to deposit ratio. Furthermore, it means that this indicator is objective in presenting movements of banking market in SEE-8 countries, so it will be the element of model presented in previous chapter.

Figure 5. Rate of loan capacity in SEE-8

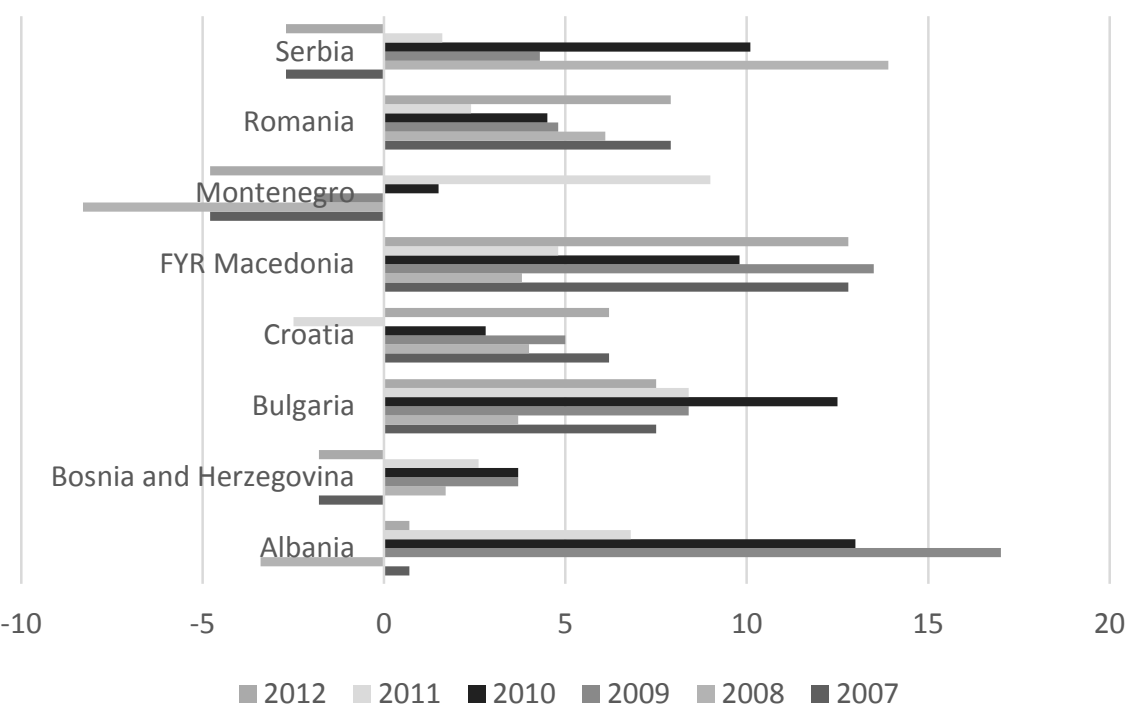

Source: RZB (2012, 2013) Raiffeisen Research: CEE banking sector Report, 2012 and 2013; Sites of central banks of SEE-8.

Rate of retail deposits is shown in Figure 6. Moreover, the rate of retail deposits of SEE-8 is relatively low and had fluctuations during the analysed period with main tendency to achieve the level which was at the begging analysed period (USAID \& CLDS, 2012). It can be concluded that it was the result of implemented measures by central banks in order to keep banking stability and non-liquidity of corporates. In the case of Serbia, those results can be explained additionally with development of cash funds, which were more attractive investment alternative for individuals (higher interest rate).

SEE-8 retail deposits participated more than $50 \%$ in total banks' deposits since 2010 (Figure 7). Accordingly, banks' business model should be based on stable sources of financing such as retail deposits (Rixtel and Gasperini, 2013). 
Filipović S. et al.: The Significance of Domestic Financing for Economic Growth in the..

Figure 6. Rate of retail deposits in SEE-8

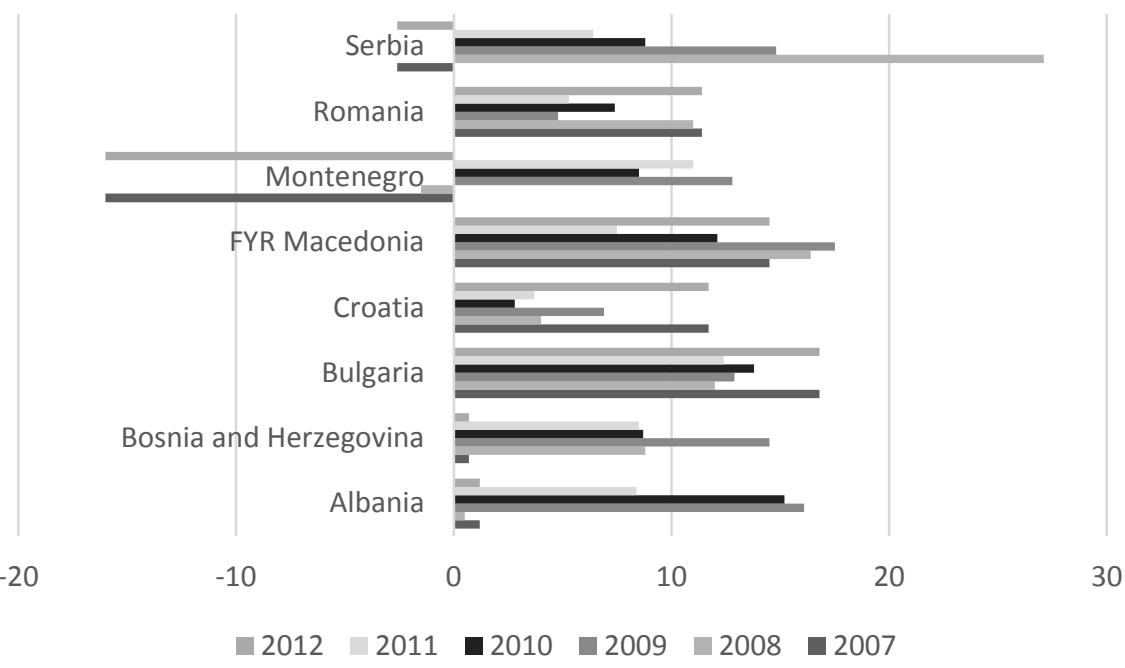

Source: RZB (2012, 2013) Raiffeisen Research: CEE banking sector report, 2012 and 2013; Sites of central banks of SEE-8.

Figure 7. Participation of retail deposits in total deposits in SEE-8

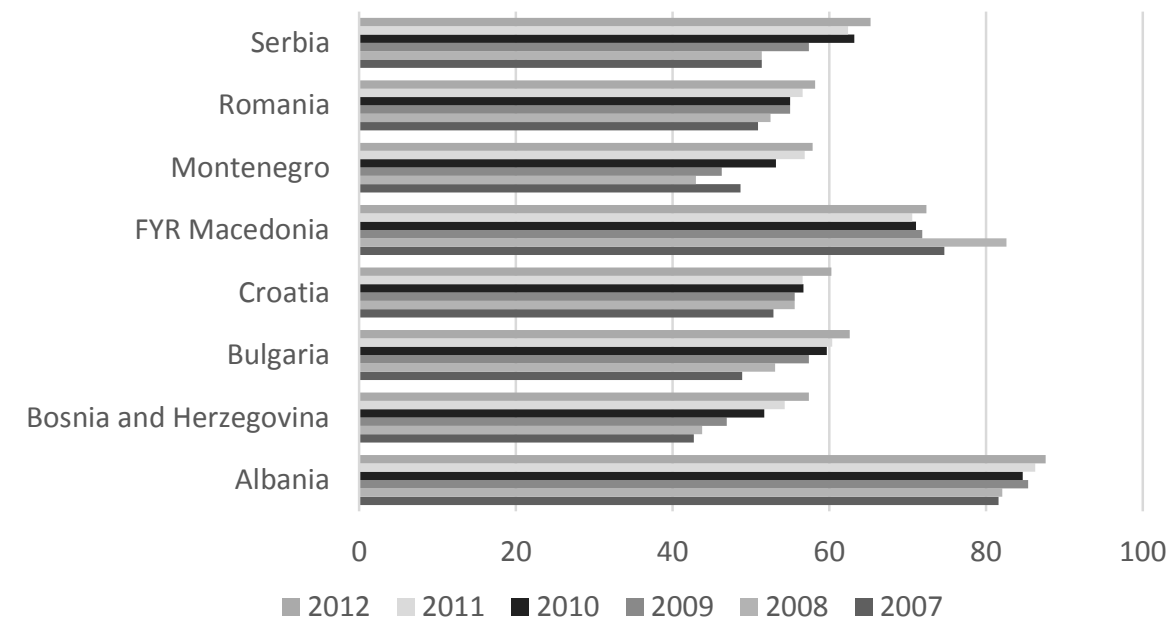

Source: RZB (2012, 2013) Raiffeisen Research: CEE banking sector report, 2012 and 2013; Sites of central banks of SEE-8.

Industrija, Vol.44, No.1, 2016 
Filipović S. et al.: The Significance of Domestic Financing for Economic Growth in the..

\section{Results of research and discussion}

The proposed panel regression model, which includes eight previously mentioned variables (the dependent one and seven independent variables) for SEE- 8 countries in six consecutive years, might be considered viable and acceptable if the initial assumptions of regression are met. In order to obtain a reliable estimate of regressor coefficients, and thus a valid model, a preliminary analysis was carried out. It included the following steps: detection of unusual, yet influential data, testing for heteroscedasticity, multicollinearity and linearity.

Unusual data in the series are those that deviate significantly from the average, or are distracting (so-called outliers; leverage), and they are identified on the basis of the value of residuals and Cook's D and DFITS values, while the affluence of independent variables are measured by DFBETA value. The above-mentioned values, derived from the analyzed data, meet the initial assumptions of the model. The assumption of homoscedasticity was tested by Cook-Weisbrg test, and based on the obtained results $(x 2(1)=6.12, p$-value $=0.063)$, the null hypothesis could not be rejected. The obtained mean, VIF $=7.18$, points to the absence of multicollinearity, thus indicating a steady regression model. Upon plotting the standardized residuals for each independent variable of the regression model, there was a discernible linearity.

Having completed the initial assumptions of the regression model, the next step is to choose an appropriate type of panel regression model. Therefore, the Hausman test was carried out, which yielded the value of 3.30 for the Hausman statistics, with $p$-value $=0.045$, leading to null hypothesis being rejected. Thus, the fixed effects model (FE) was recommended to be used instead. Table 2 contains the estimated regression coefficients of the mentioned model.

The empirical model shows a statistically significant positive effect of the assets growth rate on the GDP growth rate $(p-$ value $=0.000)$. On average, if assets are increased by $1 \%$, GDP growth of $0.162 \%$ is expected. This result indicates a huge impact of assets to GDP for the analyzed countries. Also, the rate of retail deposit and participation of retail deposit have a statistically significant positive effect on GDP growth. In other words, if the rate of retail deposit is increased by $1 \%$, on average, $0.071 \%$ of GDP growth is expected, while the $1 \%$ growth of participation of retail deposit gains, on average, expected GDP growth is $0.011 \%$.

The resulting assessment for the regression coefficient (slope) for the rate of loan capacity was not statistically significant, and has, therefore, not been analyzed. On the contrary, statistically significant, and negative, correlation 
Filipović S. et al.: The Significance of Domestic Financing for Economic Growth in the..

has been noted between GDP growth and participation of loans in GDP, rate of retail loan capacity and rate of deposit potential recorded. Namely, if the participation of loans in GDP increases by $1 \%$, on average, GDP is expected to decline to $0.009 \%$. Also, the growth rate of retail loan capacity by $1 \%$ leads to a decline in GDP by an average of $0.360 \%$. Finally, the growth rate of deposit potential by $1 \%$ leads to a drop in GDP of $0.216 \%$.

Table 2. The panel regression model

\begin{tabular}{|l|c|c|c|c|}
\hline \multicolumn{1}{|c|}{ Growth rate of GDP } & Coefficient & Std.Err. & t-statistic & p-value \\
\hline Growth rate of assets & 0.162 & 0.150 & 1.08 & 0.000 \\
\hline Rate of loan capacity & -0.011 & 0.132 & -0.08 & 0.482 \\
\hline $\begin{array}{l}\text { Participation of loans } \\
\text { in GDP }\end{array}$ & -0.009 & 0.128 & -0.07 & 0.041 \\
\hline $\begin{array}{l}\text { Rate of retail loan } \\
\text { capacity }\end{array}$ & -0.360 & 0.101 & -0.36 & 0.000 \\
\hline $\begin{array}{l}\text { Rate of deposit } \\
\text { potential }\end{array}$ & -0.216 & 0.131 & -1.65 & 0.001 \\
\hline Rate of retail deposit & 0.071 & 0.097 & 0.73 & 0.012 \\
\hline $\begin{array}{l}\text { Participation of retail } \\
\text { deposit in total } \\
\text { deposit }\end{array}$ & 0.011 & 0.187 & 0.06 & 0.000 \\
\hline Serbia & -1.248 & 12.927 & -0.10 & 0.024 \\
\hline Croatia & -3.050 & 14.616 & -0.21 & 0.037 \\
\hline $\begin{array}{l}\text { Bosnia and } \\
\text { Herzegovina }\end{array}$ & -1.024 & 12.235 & -0.05 & 0.010 \\
\hline Montenegro & -0.281 & 12.458 & 0.01 & 0.084 \\
\hline Macedonia & 0.469 & 17.834 & 0.03 & 0.019 \\
\hline Romania & -1.024 & 11.726 & -0.09 & 0.031 \\
\hline Bulgaria & -0.339 & 14.456 & -0.02 & 0.027 \\
\hline Albania & 1.953 & 17.099 & 0.11 & 0.010 \\
\hline 2007 & 8.832 & 3.698 & 2.39 & 0.029 \\
\hline 2008 & 5.561 & 2.702 & 2.06 & 0.035 \\
\hline 2009 & -3.190 & 1.454 & -2.19 & 0.042 \\
\hline 2010 & 1.091 & 1.205 & 0.91 & 0.378 \\
\hline 2011 & 2.600 & 1.179 & 2.21 & 0.042 \\
\hline 2012 & 2.580 & 1.239 & 1.98 & 0.021 \\
\hline $\begin{array}{l}\text { Number } \\
\text { observation }\end{array}$ & 42 & & & \\
\hline F-statistic & 11.6 & & & \\
\hline p-value & 0.000 & & & \\
\hline & & & & \\
\hline
\end{tabular}

Source: Own calculations. 
Filipović S. et al.: The Significance of Domestic Financing for Economic Growth in the..

In order to establish the extent to which each country individually affects the considered dependent variable, due to their other characteristics, which are not quantified here, or nor taken into account, dummy variables were introduced. Calculated estimations of regression coefficients for the introduced dummy variables, for all observed countries, can be considered statistically significant, except for the coefficient obtained for Montenegro. For each country, the resulting value of its dummy variable actually reflects the overall impact of all factors on the growth of its GDP, along with their own economic environment, which are not covered by selected independent variables. In the empirical model thus obtained, the estimated specific contribution to GDP growth is the most prominent in case of Albania, and the least for Croatia. Clearly, those countries with positive values have a higher specific contribution to GDP growth, which is not a consequence of changes in seven observed independent variables. On the other hand, for countries with a negative value of the regression coefficient of dummy variables, GDP growth was burdened by the negative impact of their particular, unquantified factors. Based on these results, the sequence of specific contribution for the subject countries is as follows: Albania, Macedonia, Bulgaria, Romania, Bosnia and Herzegovina, Serbia and Croatia.

The second part of the review is based on similar principle, but here it takes into account the overall economic environment existing at a given moment as a common factor of influence on all of the countries in the region. Analyzing the cross-sections for six consecutive years, in order to obtain regressor coefficients for each of the observed years, dummy variables were introduced. Calculated values of coefficients, representing the intercepts, indicate the cumulative impact of all unobserved factors on GDP growth, specific to each of the observed years.

The above table shows that, general economic environment was the most favourable in 2007, while during 2009 it was the worst. The obtained regression coefficients are statistically significant at the 0.05 level of significance, except the coefficient obtained for 2010. It is evident that there is only one negative regression coefficient for dummy variable, for the year 2009, which indicates the smallest GDP growth for that year, during the analyzed period. The maximum value of the regression coefficient of dummy variables is for 2007, and it shows the highest GDP growth in that year, for the reference period. There is an obvious GDP growth after the economic crisis, but the growth of GDP during the last analyzed year is significantly less than in the first year of observed period. The resulting model was statistically significant with an F - statistic of 6.11 and $p$ - value $=0.000$. 
Filipović S. et al.: The Significance of Domestic Financing for Economic Growth in the..

\section{Conclusion}

Having in mind that SEE-8 countries have underdeveloped financial market, banking sector has an important role in financing economic growth in these countries. Banking loans are approved on foreign capital and domestic deposits. In the light of global economic crisis, it is interesting to analyse the significance of domestic sources on economic growth in SEE-8 countries.

The analysis covered SEE-8 countries in the period 2007-2012. The research was based on data panel model where growth of GDP is dependable variable, while there was seven undependable variables including: growth rate of assets, rate of loan capacity, participation of loans in GDP, rate of retail loan capacity, rate of deposit potential, rate of retail deposit, participation of retail deposit in total deposit.

Comparing indicators for SEE-8 in the analysed period it could be concluded that the growth rate of assets, rate of loan capacity and rate of retail loan capacity have the same trend in the analysed period. Accordingly, the rate of deposit potential and rate of retail deposit potential have the same trend. These variables had the highest values in 2007, while in the next two years they recorded decrease and the lowest values were in 2012. Analysing indicators by the countries, Montenegro and Romania had the most dramatic drop in majority of analysed indicators, while Serbia and Albania missed the average values in terms of liability's indicators. Finally, WB countries had better values of indicators comparing to $3 \mathrm{EU}$ countries.

The results of research confirmed that growth rate of assets, rate of retail deposit and participation of retail deposit have statistically positive influence on economic growth in SEE-8 countries. On the other hand, there is a negative effect of participation of loans in GDP, rate of retail loan capacity and rate of deposit potential on economic growth.

The model introduced dummy variables to determine the extent to which each country individually affects economic growth and thus it was found that, for all countries (except for Montenegro) there is a statistically significant influence of factors that reflect the specificities of each country, and which have not been covered with the analyzed seven independent variables. Having used dummy variables, it was determined that, over the analyzed time period, the cumulative impact of all unaccounted factors on the rate of economic growth was most pronounced in 2007. 
Filipović S. et al.: The Significance of Domestic Financing for Economic Growth in the..

\section{References}

András, S. (2011). Macro to Micro: New Focus in Financial Stability. In A. Csajbok \& E. Gnan (Eds.), The Future of Banking in CESEE after the Financial Crisis. (pp. 1529). Vienna: SUERF - The European Money and Finance Forum.

Baltagi, B. (2008). Econometric Analysis of Panel Data. Wiley.

Barjaktarović, L., \& Dimić, M. (2014). Performance of banking sector in crisis: Case of SEE countries. Germany: Lambert Academic Publishing.

Barjaktarović, L., Filipović, S., \& Dimić, M. (2013). Concentrationlevel of the bankingindustry in CEE countries. Industrija,41(3), 39-53.

-BIS. (2012). . BIS quarterly review,

Cecchetti, S., Mohanty, M., \& Zampolli, F. (2011). The real effects of debt. BIS Working Papers, 352,

Chang, H.L., Chi-Wei, S., \& Meng-Nan, Z. (2011). Flexible Fourier Stationary Test in GDP per capita for Central Eastern European Countries. In Zbornik radova Ekonomskog fakulteta u Rijeci/Proceedings of Rijeka Faculty of Economics. (pp. 51-63).

Cheng, H. (2003). Analysis of Panel Data. Cambridge: Cambridge University Press.

Chowdhury, I., \& Keller, L. (2012). Managing Large-Scale Capital Inflows: The Case of the Czech Republic, Poland and Romania. IMF Working Paper, 12(138), May 01.

Christensen, R.P., \& Klyver, K. (2006). Management consultancy in small firms: how does interaction work. Journal of Small Business and Enterprise Development, 13(3), 299-313.

Cocozza, E., Colabella, A., \& Spadafora, F. (2011). The impact of the global crisis on SEE. IMF. WP/11/300.

Crisman, J.J., \& McMullan, W.E. (2000). A Preliminary Assessment of Outsider Assistance as a Knowledge Resource: The Longer-Term Impact of New Venture Counseling. Entrepreneurship: Theory \& Practice, 24(3), 41-57.

Drucker, P. (2003). The New Realities. New Brunswick (U. S. A.): Transaction Publishers; London (U.K.).

-EBRD. (2013). Transition Report: Stuck into transition. Retrieved from www.ebrd.com

-European Central Bank. EU Banking structure 2010, EBF, European banking sector: Facts and figure.

Filipovic, S. (2012). The influence of the current crisis on Balkan countries on their way to the EU integration processes. InEuropean Integration process in Western Balkan Countries. (pp. 672-691). Faculty of Economics of the University of Coimbra.

Filipovic, S., \& Miljkovic, M. (2014). Transition economies during global economic crisis: A difference in differences approach. Industrija, 42(3), 23-39.

Gelman, A., \& Hill, J. (2007). Data analysis using regression and multilevel/hierarchical models. New York: Cambridge University Press.

Greene, W.H. (2008). Econometric analysis, 6th ed. Upper Saddle River, N. J: Prentice Hall.

Hamilton, L. (2006). Statistics with Stata. Thomson Books/Cole. (updated for version 9). 
Filipović S. et al.: The Significance of Domestic Financing for Economic Growth in the..

Herrmann, S., \& Mihaljek, D. (2010). "The Determinants of Cross-border Bank Flows to Emerging Markets: New Empirical Evidence on the Spread of Financial crises. BIS Working Papers, Basel, 315, July.

-IMF. (2012). World Economic Outlook Databases. Washington, DC: IMF.

-IMF. (2013). Regional Economic Issues Central, Eastern and South-Eastern Europe.

Jurman, A. (2008). Financial Potential of Croatian Banks, Characteristics and Growth Projection. Ekonomska istrazivanja,22(1),

Kohler, U., \& Kreuter, F. (2009). Data Analysis Using Stata, 2nd ed. Stata Press. ISBN-10: 1-59718-046-7.

Marinković, S., Malović, M. (2012) Serbian credit market after the turmoil. MANAGING STRUCTURAL CHANGES, Faculty of Economics of the University of Coimbra, p. 278-302.

Malović, M. Paunović, S. (2012) Flow of funds in Balkan banks: Narrow banking or narrow escape? EUROPEAN INTEGRATION PROCESS IN WESTERN BALKAN COUNTRIES, Faculty of Economics of the University of Coimbra, $p$. 564-588.

Mihaljek, D. (2011). Domestic bank intermediation in emerging market economies during the crisis: Locally owned versus foreign-owned banks. BIS Working Papers,

Pitić, G., Savić, N., Barjaktarović, L., \& Konjikušić, S. (2014). Impact of Different Forms of Foreign Capital Inflow on GDPpc in SEE Countries During the Crisis. Eurasian Journal of Economics and Finance, 2(2), 70-77.

Popovici, A.N. (2012). Mergers, acquisition and banking consolidation in Central and Eastern Europe. CES Working Papers, 5(4),

Rixtel, A., \& Gasperini, G. (2013). Financial crises and bank funding: Recent experience in the euro area. BIS Working Paper, 406, March.

-RZB Group. RZB Research, CEE Banking Sector Report, period 2007 to 2012.

Savić, N., Barjaktarović, L., \& Konjikušić, S. (2014). Foreign capital inflow and GDPpc in CEE countries. Actual Problems of Economics, 153(3), 54-65.

Stock, J., \& Watson, M.W. (2007). Introduction to econometrics, 2nd ed. Boston: Pearson Addison Wesley.

-UNCTAD. (2011). World investment report 2011 -Non-equity modes of international production and development. New York: United Nations; Geneva.

-USAID Serbia, , \& -CLDS, (2012). Rast privatne domace štednje u cilju ubrzanja privrednog rasta Srbije. USAID projekat za bolje uslove poslovanja, 19. novembar.

-Vienna's Institute for International Economy. (2013). Statistical Review 2013.

Vujovic, D., Đenic, M., Popovcic-Avric, S., \& Konjikusic, S. (2011). Assessing the Impact of Global Crisis on European Transition Economies: The Role of Institutional Vulnerability and Resilience. In: Proceedings of the 7th International Conference of Associations of Economic Universities of South and Eastern Europe and the Black Sea Region (ASECU): Recent Economic Crisis and Future Development Tendencies, Rostov-on-Don: Rostov State University of Economics. 316-328.

Web sites of central banks SEE-8.

Wooldridge, J.M. (2001). Econometric Analysis of Cross Section and Panel Data. Cambridge: MIT Press.

The Global Competitiveness Report 2010-2011; and 2012-2013. (2013). World Economic Forum. 